\title{
Teachers' Use of Formative Assessment for the Teaching of Reading Comprehension in Grade 3
}

\author{
Hellen Ntombifuthi Mkhwanazi
}

Department of Early Childhood Education, University of Pretoria

E-mail: h.mkhwanazi@education.mpu.gov.za

Ina Joubert

Department of Early Childhood Education, University of Pretoria

E-mail: Ina. Joubert@up.ac.za

Nkidi C Phatudi

Department of Early Childhood Education, University of Pretoria E-mail: Nkidi.phatudi@up.ac.za

\author{
Wiliam J Fraser \\ Department of Science, Mathematics and Technology, University of Pretoria \\ E-mail: William.Fraser @up.ac.za
}

\section{Doi:10.5901/mjss.2014.v5n7p468}

\begin{abstract}
The low reading performance levels of Grade 3 learners in South African schools prompted this research, which was a qualitative and interpretative case study focusing on teachers' use of formative assessment when teaching reading comprehension to Grade 3 siSwati-speaking learners. Data was collected in semi-structured interviews with seven teachers at four primary schools in the Mpumalanga province and through lesson observations and analysis of learners' workbooks. Interviews were taped and transcribed. Data from the three sources was analysed and reported in an integrated way through themes. The conceptual framework was developed from various theories and concepts, namely Vygotsky's theory of learning and socio-cultural perspective (1978), Engeström's activity system model (1987) and the formative assessment process (Harlen, 2000; Ruiz-Primo, 2011; Birenbaum, Kimron, Shilton \& Shahaf-Barzilay, 2009). Evidently, effective use of formative assessment for reading comprehension requires collaboration between teachers and learners, teachers who possess the requisite knowledge of teaching reading comprehension as well as of pedagogy, and the involvement of learners in the assessment. Numerous impediments to effective formative assessment were identified: teachers' lack of knowledge of teaching reading comprehension and formative assessment, failure to plan its use, to set clear goals and to explain how to reach them, lack of feedback to learners and no development of learner self-assessment. External factors included a lack of materials for teaching reading to siSwati-speaking learners. It is recommended that the respective departments of education should train Foundation Phase teachers in the necessary skills to teach reading comprehension and provide a variety of suitable reading materials.
\end{abstract}

Keywords: Formative assessment feedback, Foundation Phase, Grade 3 learners, reading comprehension, SiSwati-speaking learners

\section{Introduction}

Reading comprehension is a basic literacy skill that should be facilitated and learned from the early school years. Learners in the Foundation Phase experience reading comprehension problems, and this inability to decode printed texts negatively affects learning and understanding of other subjects (Richeck, Caldwell, Jennifer \& Lerner, 1996).

Formative assessment, which requires teachers to communicate assessment data to learners and to use the data to plan for instruction, is one of the most effective classroom interventions to support teaching and improve learners' learning (Black \& Wiliam, 1998). This study set out to investigate how teachers use formative assessment to support the teaching of reading comprehension. The research was carried out in the Ehlanzeni district of Mpumalanga Province, 


\section{South Africa.}

\section{Rationale for this Study}

The grade 4 and 5, Progress International Reading Literacy Study (PIRLS) for 2011 (Howie et al., 2011) indicated that South African learners perform below the international standard. Other recent studies confirmed that reading skills are quite poor; many learners in Grades 4 and 5 struggled with higher-order comprehension skills such as interpretive, inferential, analytical and critical reading (Howie et al, 2011). The low achievement levels of South African learners in reading comprehension were also reported in SACMEQ III (Moloi \& Chetty, 2010). SACMEQ III indicated that overall performance in basic reading is at $21 \%$, while achievement in higher-order comprehension is below $20 \%$. The overall low results and patterns in the Annual National Assessment (ANA) in Grade 3 Literacy confirm these conclusions. The 2012 ANA qualitative report indicated an improvement in Grade 3 learners' performance better in literal comprehension, while the majority of learners struggled to interpret and integrate ideas and information (DBE, 2012). As regards reading comprehension, the ANA reported that the majority of learners were unable to respond to questions correctly; left blank spaces without providing the answer; simply transcribed the questions and failed to construct sentences to respond to the text. These reading comprehension problems were common especially in learners in rural areas and historically disadvantaged township schools (DBE, 2012).

The reason for focusing on formative assessment to enhance the teaching of reading comprehension was that in the international literature formative assessment is highly recommended to support learning and to inform teaching. There is substantial evidence on literature to confirm that effective practice of formative assessment enhances learners' performance and improve the standards (Taras, 2009), and in fact numerous educational institutions around the world have adopted it.

In South Africa, however, little research has been conducted on formative assessment of Foundation Phase learners (Grades $\mathrm{R}$ to 3). The research aimed to obtain evidence-based data on the facilitation of formative assessment activities in this phase. According to the DBE (2007), formative assessment should be administered within the assessment guidelines of the Provincial Education Department, which comply with the National Policy on Assessment.

Although confined to a small part of a specific population, this research study will hopefully contribute to the body of evidence-based knowledge on the formative assessment activities of Grade 3 teachers when teaching reading comprehension.

\section{Purpose of the Study}

The specific aim of this research study was to describe, explore and obtain evidence-based data on the facilitation (or otherwise) of formative assessment in the teaching of reading comprehension in Grade 3. This could shed light on the low reading levels of learners in the Foundation Phase. The general aim of the study was to contribute to the improvement of policy and practice regarding the role of formative assessment in teaching reading comprehension.

\section{Research Questions}

The main research question was: siSwati?

How do grade 3 teachers use formative assessment to enhance the teaching of reading comprehension in

To find the answer to the main question, it was broken down into the following aspects:

- What are the teachers' conceptions of the role of formative assessment in teaching of reading comprehension to Grade 3 learners?

- How do Grade 3 teachers employ formative assessment when teaching reading comprehension in siSwati?

- What is the nature of feedback given by Grade 3 teachers when teaching reading comprehension in siSwati?

\section{A Theoretical Framework for Formative Assessment of Reading Comprehension}

Knowledge of learning processes is important for planning the formative assessment of reading comprehension. Without this knowledge, teachers cannot design and use appropriate teaching and formative assessment strategies. Pryor and Crossouard (2008) see formative assessment as taking place when both teachers and learners seek to respond to learners' work - by implication, formative assessment is a means to enhance learning. 
Various theories and concepts have been identified about what works in formative assessment, namely Vygotsky's theory of learning, socio-cultural perspective (1978), Engeström's activity system model (1987), the formative assessment process (Harlen, 2000; Ruiz-Primo, 2011; Birenbaum, Kimron, Shilton \& Shahaf-Barzilay, 2009) and self-regulated learning (Zimmerman, 1998). Clearly, effective use of formative assessment for reading comprehension requires collaboration between teachers and learners, such as learner involvement in the five phases of formative assessment of reading comprehension.

Vygotsky (1978) proposed a theory, commonly known as constructivism, about how people construct knowledge. This theory has been widely used in the education sector all over the world (Nie, Tan, Liau, Lau \& Chua, 2012). According to this theory, learning requires active engagement of the learners (James, 2006; Nie et al., 2012). Vygotsky (1978) holds the view that learners are the constructors of their own knowledge and skills. He argues that learners should engage their thinking skills to construct knowledge for themselves (Block \& Pressley, 2002). In other words, the learner should be cognitively active and stimulated in order for learning to take place in the classroom where self-exploration and independent learning are promoted.

In constructivism, prior knowledge is regarded as influential for the construction of new knowledge (James, 2006). Prior knowledge refers to knowledge, ideas and experiences which the learner brings to the classroom. The implication is that knowledge is a product of individuals, and learners should make reference to what they know in order to construct new knowledge.

The socio-cultural perspective considers the social and cultural factors as influential for learners to construct knowledge (James, 2006). According to this perspective, knowledge is a product of humans and is socially and culturally constructed. This perspective takes into account the importance of the context of the learner. The implication of the sociocultural perspective is that when learners interact with others in the environment, their experiences and interpretations of the environment help them to construct knowledge.

Researchers of formative assessment support the socio-cultural view of the practice of formative assessment (Black \& Wiliam, 2003; James, 2006; Pryor \& Crossouard, 2008). They regard the classroom as a constructive environment and a socio-cultural context. In addition, these researchers view formative assessment as collaboration between the teacher and learners. This interaction supports the learning process. James (2006) referred to the relationship between individual thinking and the environment, arguing that individual thinking is influenced by factors in the environment; conversely, the learners' encounters with their environment influence the way the learner thinks.

In support of the socio-cultural perspective, Engeström developed the activity system theory, which is based on the idea that learning is a collaborative and authentic activity. There should be a system between a human and social component in order to accomplish the activity (Engeström, 2001). The activity system theory provides the appropriate framework for understanding human activities and provides focus for designing the constructivist learning environment (Yamagata-Lynch \& Smaldino, 2007).

Another critical aspect of formative assessment is that assessment should be self-regulated. Daly, Pachler, Mor and Mellar (2010) endorse this when they state that formative assessment should activate learners as owners of their own learning and instructional resource. Zimmerman (1998) proposed a model for self-regulated learning which involves monitoring and control of behaviour, cognition and motivational beliefs during learning. Self-regulation of behaviour refers to active control of resources which are available to the learner. Cognition is the conscious mental process by which knowledge is accumulated and constructed (Barak, 2010), whereas motivation involves controlling motivational beliefs such as self-efficacy and goal orientation (Barak, 2010). Zimmerman's model implies that learners need to accept responsibility and accountability for their comprehension abilities by setting own targets and determining whether targets have been reached.

Zimmerman described self-regulation as a cyclical process consisting of three phases, namely forethought, performance and self-reflection. The forethought phase involves goal-setting and strategic planning. The performance phase involves strategy implementation and self-monitoring. The self-reflection phase involves evaluation and monitoring of strategic outcomes (Barak, 2010). He noted that for self-regulation to take place in the classroom environment, learners should carry out all these phases by themselves. Zimmerman's model of self-regulation has been tested several times and proven to be successful in research studies (Barak, 2010).

It is argued that formative assessment should empower learners to develop skills for self-regulated learning (Nicol \& Macfarlane, 2006; Bennett, 2011). According to Bennett (2011), sharing clear learning goals, effective questioning, effective feedback and self and peer-assessment are intended to help learners to take ownership of their learning. 


\section{Research Method}

This study followed a qualitative approach. Qualitative methods are probably the best means for uncovering educational problems and enable researchers to better understand the total environment in which education takes place. An interactive qualitative research approach was used, as I gathered information in person by interacting with participants in their location (MacMillan \& Schumacher, 2010). Data was collected by observing lessons, conducting semi-structured interviews scheduled with individual teachers and by analysing teachers' lesson plans and learners' workbooks.

Purposive and convenient sampling techniques were used. Case studies of seven teachers were conducted in four schools from the same district, conveniently located not very far from my work station. The teachers were in their first year of implementing the Curriculum and Assessment Policy Statement (CAPS) with Grade 3 learners in 2012, which was the first year of the implementation of the National Curriculum Statement (NCS) after its revision.

The case study was instrumental, explorative and descriptive. The units of analysis for this research project were Grade 3 teachers and their application of formative assessment. I also observed Grade 3 learners during the implementation of formative assessment, as I was interested in the interaction between teachers and learners in the form of feedback.

\section{Data Analysis}

I applied the within-case and cross-case analysis as suggested by Merriam (2009). In within-case analysis, each case is treated as a comprehensive case in and of itself and analysed separately, while cross-case analysis involves the identification of similarities or patterns across cases as well as differences, which enables abstractions to be built across cases.

I used both inductive and deductive data analysis approaches. The two main concepts of this study (formative assessment and reading comprehension) provided a foundation for analysing the findings of the research on an a priori basis, where the researcher uses a deductive approach and the themes required from the data are formulated in advance (Nieuwenhuis, 2007).

\section{Summary of the Research Findings}

The data obtained from the study was reported in three themes, namely uncertainty about formative assessment, inconsistent practice of formative assessment and challenges faced by teachers in the facilitation of reading comprehension.

\subsection{Uncertainty about formative assessment}

According to Reddy (2004), assessment should be designed with one of four specific purposes in mind: baseline, summative, formative and diagnostic (DBE, 2011). Formative assessment refers to all assessment activities undertaken by teachers during the learning process, the intention of which is to support learners' learning through feedback (Black \& Wiliam, 1998).

The interviews revealed that teachers' understanding of formative assessment differed. On the basis of their responses, the teachers could be divided into two categories: those with limited knowledge and those with reasonable knowledge of formative assessment.

Five teachers were only aware of the summative function of assessment: they said that it was used to measure the learner's performance after the teacher had taught, i.e. at the end of the learning process. Their paradigm was: the teacher teaches, learners learn and the teacher assesses. These teachers were obviously missing the point of formative assessment.

On the other hand, three teachers displayed a reasonable knowledge of formative assessment, describing it as a process that should take place in all three phases of the learning process - in the beginning, during and towards the end of the lesson. They also mentioned various purposes and aspects of formative assessment and were able to explain each purpose at the various stages of the learning process.

\subsection{Inconsistent practice of formative assessment}

The study revealed that teachers were unable to use formative assessment to support learning, especially to enhance 
their reading comprehension. Teachers frequently asked only lower-order questions to assess reading comprehension; such questions merely required learners to extract information from the texts and did not activate them to think or to enhance their metacognitive skills.

It was also found that teachers lacked basic information about feedback; they considered it to be merely the corrections teachers and learners engaged in after the written tasks. They did not see feedback as an intervention to support learners' improvement. Few teachers made effective comments; most of them simply gave the learners ticks, marks and evaluative comments such as "good"; "very good"; "You are a star".

Overall, teachers were found to dominate the lessons: they usually gave instructions to the learners and learners act on teachers' instructions. The assessment criteria were not shared with the learners, and learners were not capacitated to develop and practice self and peer-assessment skills.

\subsection{Challenges faced by teachers in facilitating reading comprehension}

According to Heritage (2007), teachers need specific knowledge and skills in order to implement formative assessment successfully. They should know the concepts and skills to be taught which are peculiar to the subject and possess pedagogical content knowledge and assessment knowledge. However, in this study all teachers complained that they were not getting adequate support for teaching and assessing reading comprehension and that there were neither guideline documents on how to use formative assessment nor sufficient reading resources for teaching reading comprehension.

\section{Limitations of the Study}

This was a baseline study of teachers' practice of formative assessment. It reports what was observed in the classroom and what was communicated by the teachers. But, being a case study, only schools within practical reach could be studied, which confined the sample to a specific geographical area in Mpumalanga. This is a largely rural area with many low-income families, and unemployment and migrant labour are common. While this socioeconomic situation also exists in many other regions in South Africa and some generalisation is possible, the relative power of the qualitative analyses of this study and the generalizability of the findings would be increased if a future study were undertaken to include more developed metropolitan areas and other population groups.

Lastly, this study did not address the question whether formative assessment as a method 'delivers the goods'. There is sufficient evidence (and practical proof) that if applied correctly, it works. But the study also showed that, like with any other method, there would have been little point in evaluating the results of formative assessment of reading skills as acquired by an incorrectly applied method.

\section{Recommendations}

\subsection{Recommendations to the Mpumalanga Department of Education}

The MDoE should support teachers through professional development programmes focusing on giving teachers the knowledge of strategies for teaching reading comprehension and doing formative assessment for reading comprehension. Workshops on the application of formative assessment should be given in other subjects as well in teaching reading comprehension, and should also cover knowledge of the principles and key components of formative assessment such as strategies for effective feedback to the learners, effective use of questioning, self-assessment and peer-assessment and other forms of active learner participation. These workshops should be facilitated by experts in the field of formative assessment.

Professional development for formative assessment should be ongoing and take place regularly over a period of time. It should provide direct instructions and practical examples in order for teachers to acquire skills and knowledge for integrating formative assessment in the teaching of reading comprehension. After the workshops, there should be close support for teachers in the classrooms. The MDoE, using experts in formative assessment, should guide and support teachers when implementing formative assessment in their classrooms. They should also guide teachers by providing practical examples from the learners' workbooks to interpret formative assessment data so that they can adjust their teaching of reading comprehension. The support should focus on the deepening of teachers' knowledge of the subject content and responses to learners and strategies.

The MDoE should introduce enquiry-based learning to teachers in their own classrooms. This could assist teachers 
to plan, implement and evaluate their practice of formative assessment, to investigate and reflect on their classroom practice with the intention of improving on their teaching and assessment and may lead to teachers' regulation of formative assessment.

In addition to the above, the MDoE should provide schools with the necessary resources to support the implementation of formative assessment. In this case, schools should be provided with siSwati reading books and workbooks and train teachers in the use of the activities in the workbooks. The MDoE should also support schools with exemplars for formative assessment.

It is also necessary for the MDoE to empower School Management Teams (SMTs), in particular the head of department in the Foundation Phase, with skills and knowledge for formative assessment so that they will be able to support teachers and monitor the implementation of formative assessment for reading comprehension in the classrooms.

\subsection{Recommendations to the head of department in the Foundation Phase at schools}

Some teachers in the study complained that they had never been trained in curriculum matters in their schools. The reason might be that heads of departments have little knowledge of classroom practice and are therefore not equipped to manage the curriculum in this phase. Heads of departments in the Foundation Phase should learn more so as to get a better understanding of classroom practices; they need to equip themselves with knowledge of formative assessment and reading comprehension, so that they will be able to assist teachers with various strategies for teaching and assessing reading comprehension.

Heads of departments should provide support to teachers in their classroom practice. They should assist teachers in developing tasks of high quality and ensure that teachers use a variety of questions for assessing reading comprehension and monitor the use of learners' workbooks to help them provide constructive feedback to the learners.

In addition to the above, heads of department should encourage teachers to participate in teacher learning communities for formative assessment. In Mpumalanga this usually takes place through cluster meetings, which are formal or informal meetings held with a group of teachers who reside in the same area and are meant for teachers to support one another in curriculum matters.

\subsection{Recommendations to teachers}

Teachers should learn about the theory (different relevant concepts) and assessment practices by studying information from various sources. They should participate in education programmes to improve their classroom practice and participate in cluster and school meetings to share knowledge with other teachers. This will improve their professional knowledge of and skills in the formative assessment of reading comprehension.

\subsection{Recommendations to teacher training institutions}

Besides taking note of the relevant recommendations above, teacher education and training institutions should develop and present a module on the assessment of reading comprehension. This module should include formative assessment and offer practical examples of formative assessment to enhance the teaching of reading comprehension in the Foundation Phase.

\subsection{Recommendations for further research}

The following are ideas for further research:

A baseline study that includes many teachers from various districts should be conducted to get a broader picture of teachers' use of formative assessment in the province.

An in-depth study that explores and develops various components of formative assessment in the subject languages (e.g. teachers' use of feedback, self and peer-assessment, effective questioning).

A research study that will focus on how teachers use formative assessment to improve learners' learning.

Research that will focus on the use of formative assessment for self-regulated learning.

A participatory action research study that will focus on developing formative assessment knowledge and skills for the teaching of reading comprehension.

A large-scale intervention programme to support teachers with the implementation of formative assessment when teaching reading comprehension. 


\section{Conclusion}

The study indicated that teachers did not use formative assessment to enhance the teaching of reading comprehension. Teachers' feedback did not stimulate learners to revise their work and expand their thinking. As it was a small case study, the findings can hardly be generalised. However, the study does show that teachers' assessment practices may detract from the development of learners' comprehension skills, as formative assessment implemented properly elsewhere has been proven to support teaching and improve learning. In his sense, the findings of this study may provide pointers for schools facing the challenge of low performance levels in reading comprehension, as revealed by the ANA results.

Furthermore, the findings of this study may raise awareness at the Department of Basic Education generally that teachers must be supported with knowledge and skills in formative assessment in order to improve their teaching and to support reading comprehension. There is a critical need for teachers' professional development in formative assessment in order for them to reap the benefits of this approach. Professional development programmes should focus on supporting teachers with the integration of formative assessment in their teaching experience. In addition, teachers should learn skills in providing learners with effective feedback that will support the learners' learning in general and in reading comprehension specifically.

Ultimately, the ability to understand a written text is an absolutely fundamental life skill that is essential for all school subjects and life beyond the school environment as well. Failure to teach this skill successfully may handicap the development of our children for the rest of their lives.

\section{References}

Barak, M. (2010). Motivating self-regulated learning in technology education. International Journal of Technology Education, 20(4), 381401.

Bennet, R.E. (2011). Formative assessment: A critical review. Assessment in Education: Principles, Policy \& Practice, 18(1), 5-25.

Birenbaum, M., Kimron, H., Shilton, H. \& Shahaf-Barzilay, R. (2009). Cycles of inquiry: Formative assessment in service of learning in classrooms and in school-based professional communities. Studies in Educational Evaluation, 35, pp. 130-149.

Black, P. \& Wiliam, D. (1998). Assessment and classroom learning. Assessment in Education: Principles, Policy \& Practice, 5(1), 103110.

Black, P. \& Wiliam, D. (2003). In praise of educational research; Formative assessment: British Educational Research, 29(5), 632-637.

Block, C.C. \& Pressley, M. (2002). Comprehension Instruction: Research-Based Best Practice $\left(2^{\text {nd }} \mathrm{ed}.\right)$. London: The Guilford Press

Daly, C., Pachler, N., Mor, Y. \& Mellar, H. (2010). Exploring formative e-assessment: Using a case stories and design patterns. Assessment \& Evaluation in Higher Education, 35(5), 619-636.

Department of Education. (2007). Assessment Guidelines for Foundation Phase Grade R-3. Pretoria: Government Printers.

Department of Basic Education. (2012). Report on the Annual National Assessment. Pretoria: Government Printers.

Engeström, Y. (2001). Expansive Learning at Work: Toward an activity-theoretical reconceptualization. Journal of Education and Work, $14(10), 133-156$.

Harlen, W. (2000). Teaching, learning and assessing science (3rd ed.). London: Paul Chapman Publishing.

Heritage, M. (2007). Formative assessment: what do teachers need to know and do? Phi Delta Kappan, (89)2, 140-144.

Howie, S.J., Van Staden, S., Tshele, M., Dowse, C. \& Zimmerman, L. (2011). PIRLS 2011 Summary Report: South African children's reading literacy achievement. South Africa: University of Pretoria. Centre for Evaluation and Assessment.

James, M. (2006). Assessment, teaching and theories of learning. In J. Gardner (Ed.). Assessment and Learning (pp. 47-60). London: Sage.

MacMillan, J.H. \& Schumacher, S. (2010). Research in education: Evidence based inquiry (7 $7^{\text {th }}$ ed.). New York: Addis Wesley Longman.

Merriam, S.B. (2009). Qualitative Research: A guide to design and implementation. San Francisco: Jossey-Bass Publications.

Moloi, M. \& Chetty, M. (2010). The SACMEQ III Project in South Africa: A study of the Conditions of Schooling and the Quality of Education. Pretoria: South Africa.

Nicol, D.J. \& Macfarlane-Dick, D. (2006). Formative assessment and self-regulated learning: A model and seven principles of good feedback practice. Studies in Higher Education, 31(2), 199-218.

Nie, Y., Tan, G.H., Liau, A.K., Lau, S. \& Chua, B.L. (2012). The roles of teacher efficacy in instructional innovations: its predictive relations to constructivists and didactic instructions. Springer Science \& Business Media.

Nieuwenhuis, J. (2007). Qualitative research and design and data gathering. In Maree. K. (Ed.). (2011). First Step in Research. Pretoria: Van Schaik Publishers.

Pryor, J. \& Crossouard, B. (2008). A socio-cultural theorization of formative assessment. Oxford Review of Education, 34(1), 1-20.

Reddy, C. (2004). Assessment principles and approaches. In J.G. Maree \& W.J. Fraser (Eds.), Outcomes based assessment. Cape Town: Heinemann Publishers.

Richeck, M.A., Caldwell, J.S., Jennings, J.H. \& Lerner, J.W. (1996). Reading problems. Assessment and teaching strategies. Sydney: Allyn and Bacon. 
Ruiz-Primo, M.A. (2011). Informal formative assessment: The role of instructional dialogues in assessing students' learning. Studies in Educational Evaluation, 37(1), 15-24.

Taras, M. (2009). Assessment for learning: assessing the theory and evidence. Journal for Further and Higher Education, 2(1), 30153022.

Vygotsky, L.S. (1978). Mind in society. Cambridge, MA: Harvard University Press.

Yamagata-Lynch, L.C. \& Smaldino, S. (2007). Using activity theory to evaluate and improve K-12 schools and university partnership. Evaluation and Program Planning, 30(4), 364-380.

Zimmerman, B.J. (1998). Academic studying and the development of personal skills: A self-regulatory perspective. Educational Psychologist, 33, pp. 73-86. 